
\section{PP-045 前立腺導管型腺癌についての臨床病理学}

\section{東京慈恵会医科大学医学部泌尿器科学 ${ }^{11}$, 東京慈恵会医科} 大学医学部病理学講座 ${ }^{21}$

山本 順啓 ${ }^{1)}$, 鷹橋 浩幸 ${ }^{2)}$, 佐々木 裕 ${ }^{1)}$, 木戸 雅人 ${ }^{12}$, 三木 淳 ${ }^{1)}$, 林 典宏 ${ }^{1)}$, 木村 高弘 ${ }^{1)}$, 三木 健太 ${ }^{1)}$, 古田 希1), 頴川 晋1

【背景】導管型腺癌は全前立腺癌の約 0.2-0.8\%を占める稀 な組織型である。診断時すでに転移していることが多く、 予後も不良とされている。しかし、その臨床病理学的背景 は明らかでない。今回我々は、前立腺全摘術を施行し、導 管型腺癌と診断された症例について臨床病理学的検討を 行った。【方法】前立腺全摘を施行された 154 例中 11 例に 導管型腺癌を認めた。この 11 例について臨床病理学的背 景および、生検標本との比較検討を行った。【結果】平均 年龄は 63.5 歳、平均 PSA は $16.0 \mathrm{ng} / \mathrm{mL}$ であった。9 例は 通常型腺癌の混在を認め、2 例は純粋な導管型腺癌であっ た。Gleason Score は $3+4=7$ が 7 例、 $4+3=7$ が 6 例、 9 が 2 例であった。病期は pT2b が 1 例、pT3a が 3 例、pT3b が7例であった。被膜外浸潤、静脈浸潤、精囊浸潤はそれ ぞれ 10 例、 5 例、7 例に認めた。切除断端陽性を 9 例に認 めた。3例にリンパ節転移を認めた。8例にPSA 再発を認 めた。全摘標本と生検標本の間に Gleason Score の相関を 認めた。しかし、2例のみ生検標本内に導管型腺癌を認め た。【結論】導管型腺癌は最も悪性度の高い前立腺癌の一 型と考えられた。全摘標本に抢ける導管型腺癌の量に関わ らず、生検により術前診断する事は困難であると考えられ た。

\section{PP-046 当院における限局性前立腺癌に対する根 治的前立腺全摘除術後のPSA 再発に関 する検討}

\section{川崎市立川崎病院}

弓削 和之，小堺 紀英，原 智

【目的】当院に扔ける限局性前立腺癌患者に対する根治的 前立腺全摘除術後のPSA 再発について検討を行った。【方 法】 2005 年 1 月より 2009 年 3 月までに当院にて根治的前 立腺全摘除術を施行した限局性前立腺癌患者 48 例を対象 とした。なお、PSA 再発の定義は 3 回連続したPSA 值の 上昇とし、PSA 再発危険因子の検討を行った。【結果】対 象の平均年齢は 68.2 歳であり、平均観察期間は 17.5 ケ月 であった。対象のうち、治療前ホルモン療法を施行してい た症例は 8 例であり、治療前平均 PSA 值は $12.1 \mathrm{ng} / \mathrm{ml}$ で あった。摘除術によって摘出された検体の病理組織学的所 見において pT2b は 10 例、pT2c は 16 例、pT3a は 10 例、 pT3b は 10 例、Gleason score $\geqq 8$ は 11 例であった。ま た断端陽性例は 16 例、精囊浸潤例は 10 例であった。PSA 再発危険因子の検討において治療前 PSA 值と精囊浸潤の 有無に有意な差を認めた。 $(\mathrm{p}=0.019,<0.001)$ 【結論】 限局性前立腺癌患者を対象とした根治的前立腺全摘除術を 施行した場合、施行後にPSA 再発を認める危険性が高い 症例は治療前 PSA 高值例と精囊浸潤例であった。

\section{PP-047大和高田市立病院における前立腺全摘出 術症例の臨床的検討}

\section{大和高田市民病院泌尿器科 \\ 中濱 智則, 冨岡 厚志, 永吉 純一, 吉田 宏二郎, 仲川 嘉紀}

【目的】当科にて施行された前立腺全摘出術症例の治療成 績を検討した。【対象および方法】対象は 1998 年 1 月から 2009 年 9 月の期間に当科にて前立腺全摘出術を施行した 130 例を対象とした。PSAの再発は PSA 值 $0.2 \mathrm{ng} / \mathrm{ml}$ を超 えた時点とした。【結果】年齢は $49 \sim 78$ 歳 (中央值 69 歳)、 初診時 PSA は $3.92 \sim 227$ (中央值 9.54) $\mathrm{ng} / \mathrm{ml}$ 、観察期 間は $1 \sim 135$ 力月 (中央值 28 力月) であった。術前補助 療法を 45 例に、手術時に除等術を 11 例に、術後補助内分 泌療法を 17 例に行った。臨床病期は $\mathrm{T} 1: 28$ 例、 T2:44 例、 T3 : 58 例で、2 例に所属リンパ節転移を認めた。PSA 再 発は 46 例 $(35.4 \%)$ に認め、 5 年 PSA 非再発率は $56.2 \%$ であった。癌死は 3 例、他因死は 1 例認め、 5 年全生存率、 5 年疾患特異的生存率は共に $96.5 \%$ であった。除睪術、術 前術後補助療法を施行しなかった 77 例では 16 例 (20.1\%) で再発を認め、5 年 PSA 非再発率は $64.5 \%$ で、D’Amico のリスク分類別に分けると低リスク群で $90.9 \%$ 、中リスク 群で $86.2 \%$ 、高リスク群で $51.7 \%$ であった。今後さらに症 例数、観察期間を増やして検討する予定である。

\section{PP-048＼cjkstart根治的前立腺全摘術を行った高リスク前 立腺癌症例の検討}

\author{
がん・感染症センター都立駒込病院泌尿器科 \\ 市川 寛樹, 前川 滋克, 夏井 信輔, 山田 幸央, \\ 篠原 充
}

【目的】根治的前立腺全摘術を行った症例のうち高リスク 症例について臨床的検討を行った。【対象と方法】2001 年 から 2009 年 6 月まで当院で根治的前立腺全摘術を行った 高リスク症例の 50 例を対象とした。患者背景は年齢 55-76 歳 (中央值 68 歳)、術前 PSA 值は 4.67-208.97 ng/ml（中 央値 17.88)、生検 Gleason score は 6 以下 2 例、 7 が 13 例、 8 以上が 33 例。臨床病期 T1c が 1 例、cT 2 が 41 例、cT3 が 8 例だった。術前ホルモン療法は17 例に行われていた。 観察期間は2.1-104.3 (中央值 42.9) 加草った。【結果】 病理学的 T stage は pT2 24 例、 pT3a 13 例、pT3b 9 例、 pT4 4 例だった。リンパ節転移は6 例に認めた。22例 (44\%) がPSA 再発し、5 年無再発生存率は $40.6 \%$ だっ。病理学: 的パラメーターの中では SV (+)、T3 以上、ew (+) の症 例で有意にPSA 再発率が高かった（それぞれ $\mathrm{p}=0.013$ 、 0.037、0.003)。術前ホルモン療法の有無やリンパ節転移の 有無に有意差はなかった。多変量解析では ew (+) が有 意な危険因子であった（リスク比 $2.47 \mathrm{p}=0.037 ） 。 50$ 例中 2 例 (4\%) が癌死し 5 年疾患特異的生存率は $92.8 \%$ たった。 【結論】高リスク症例でも切除断端が確保できれば再発率 が低下すると考えられた。 